The Japanese Journal of Animal Psychology, 45, 2, 67-75 (1996)

\title{
講演論文
}

\author{
サル類の子育て
}

大阪大学 中道正之 ${ }^{1)}$

\section{Maternal Behavior in Non-human Primates}

\author{
MASAYUKI NAKAMICHI \\ Department of Ethology, Faculty of Human Sciences, \\ Osaka University, Suita, Osaka 565
}

\section{1.はじめに}

母ザルの出産歴，社会的な順位，子ザルの性 の違いによって,子育てがどの様に異なるのか。 子育てに影響を与えると思われるこれら 3 つの 要因を検討するために，1960 年代から 1970 年 代の終わり頃までに，主に，マカク属 (Macaca) 類のサルを対象にして，多くの研究が行われて きた。その結果，経産の母ザルに比べて初産の 母ザルは保護的である，下位の母ザルに比べて 高位の母ザルは子ザルの行動を制限する行動が 少ない, さらに，メスの子ザルよりもオスの子 ザルの方が母ザルから離れて過ごす時間が多 い，等々のように，出産歴，順位，子ザルの性 が母子関係に大きく反映されることが指摘され ている(詳細は中道, 1993 a を参照)。しかし， これらの研究のほとんどが，飼育下の小集団で 行われていること, さらに, 母子の関わりが比 較的密接な子ザルの生後 1 年以内の期間を対象

1 ) 本稿は日本動物心理学会第55回大会の講演討 論会において発表したものをまとめたもので ある。発表の機会を与えて下さった大会委員長 の糸魚川直祐先生 (大阪大学), 講演討論会の司 会の南 徹弘先生 (大阪大学), 指定討論者の根 ケ山光一先生 (武庫川女子大学) と藤田和生先 生（京都大学）に感謝いたします。
にして行われていることなどの問題点も含んで いる。マカク属のサルでは, 生後 2 年目以降で も，子ザルと母ザルの関わりは持続する。従っ て,これまでのように発達の初期段階のみに焦 点をあてた研究ではなく，もっと長期に観察を 続けることによって，これまでの研究では見逃 されてきた母子関係の態様を明らかにできると 思われる。

本稿では, 最近数年間に発表された母子関係 の論文から，長期にわたる縦断的観察で得られ た資料を呈示し，上に述べたような従来の要因 分析的な研究とは異なる「子育て」の姿を指摘 する。さらに，死んだ子ザルに対する母ザルの 反応を指標として，下等な原猿類 (Prosimiae) から高等な真猿類（Simiae）までの母ザルに共 通する母性の豊かさを指摘する。

\section{2. 子育ての恒常性}

ニホンザル（Macaca fuscata） は春から夏に かけて出産する。従って, 生後 3,4 年の間なら ば，その体つきから年齢がわかる。また，体つ きや運動能力が類似した同じ年に生まれた子ザ ルたち同士が互いに遊び相手になったり，探索 行動に出かけることが多い。そして，メスの多 くは生後 5 年目を終える頃に最初の出産を経験 する。オスも同じ頃に，成体のオスに近い性的 
能力を持つようになる。このようにニホンザル では，同じ年に生まれた子ザル同士がよく関わ りながら，数年間の子ザル時代を過ごす。この 期間に，母ザルとの関係はどの様に変化するの であろうか。例えば，母ザルと一緒にいること が多い子ザルと，母ザルから離れて過ごすこと が多い子ザルのように，同じ年に生まれた子ザ ルの間でも母ザルとの関わり方に個体差もある だろう。さらに，このような個体差は持続する のだろうか。これらの疑問を解決するために， 著者は淡路島ニホンザル集団を対象にして，同 じ年に生まれた全ての子ザルを被験体として， 生後 4 年間の縦断的観察を行った (Nakamichi, 1989)。

Fig. 1 には，ニホンザルのオスの子ザルが母 ザルの $2 \mathrm{~m}$ 以内にいた時間の割合が示してあ る。オスの子ザルは 14 頭生まれ, 生後 4 年を終 えたときには 9 頭に減っていた。破線はそれぞ れの時期における中央值。網でおおわれた領域 がレンジである。太い実線を無視して見てほし い。生後直後には，ほとんどの時間を母ザルの 近くで過ごしているが, 生後 1 年を終える頃に は半分の時間になった。生後 2 年目, 3 年目で
も，母ザルの近くにいる時間はさらに少なくな り, 生後 4 年目では約 10\%の時間を母ザルの近 くで費やすに過ぎなくなった。つまり，生後直 後の母子の密接な関係が生後 1 年を終える頃に は，かなり薄まり，それ以降も，徐々にではあ るがさらに薄まる傾向にある。これが,生後 4 年 間の母子関係の一般的傾向である。さて, 今度 はFig. 1 の太実線に注目してほしい。これは 25-76-81 と言う名前のオスの子ザルの值を示 したものである。母ザルの優劣順位は中位で, 初産。生後 4 年間の 17 期間のうちの 3 期間で, 最高值を示し, 中央值よりも低い值を示したの は, 4 期間しかなかった。つまり,この子ザルは, 成長に伴って，母ザルの近くにいる時間は減少 したが，他のオスの子ザルに比べて，比較的高 い值を示していたのである。1 頭づつ, 同様の分 析をしていくと，たいていの期間で中央值に近 い值を示すオスの子ザル，あるいは，ほとんど の期間で中央值よりも低い值を示すオスの子ザ ルがいるのである。つまり，母ザルの近くにい る時間が他の子ザルに比べて, 相対的に多い子 ザル，逆に少ない子ザルが，生後 4 年間を通し て一定であることが示唆されたのである。これ

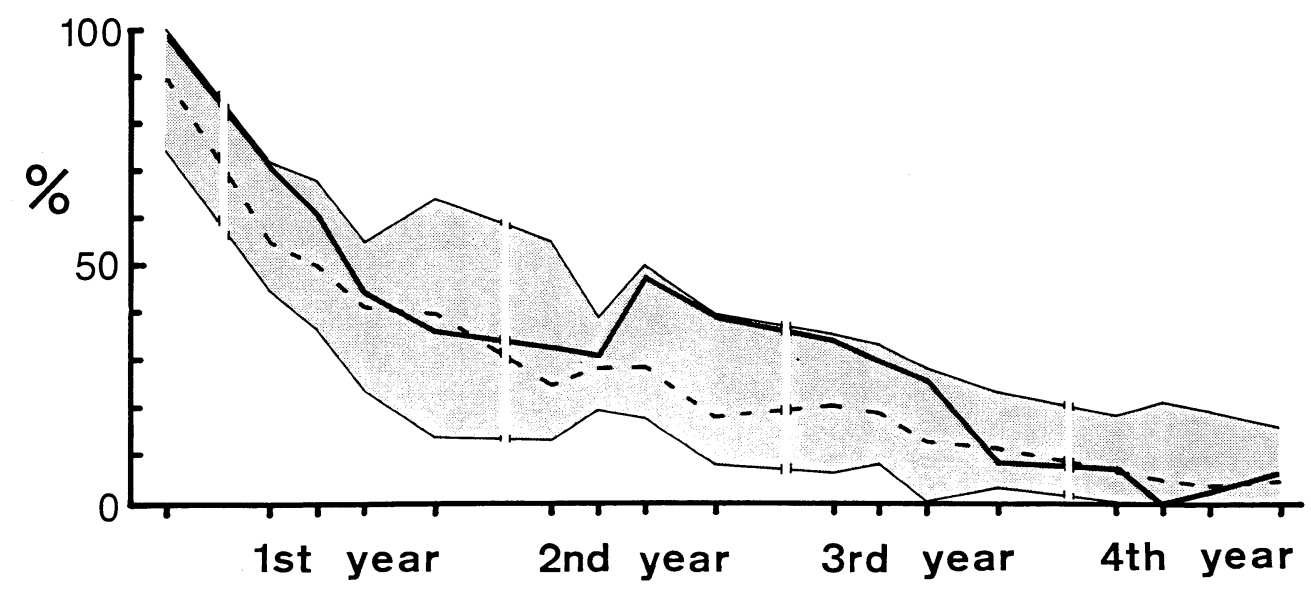

Fig. 1 Median percentage of 1-min intervals during which male Japanese monkeys were within $2 \mathrm{~m}$ of their mothers. Dotted lines and meshed areaa show the median and the range, respectively. Thick solid lines show a male juvenile, 25-76-81. 
Table 1 Kendall coeffcients of concordance $(W)$ for various behaviours observed between the subjects and their mothers. (from Nakamichi, 1989. Reprinted by permission of Academic Press)

\begin{tabular}{|c|c|c|c|c|c|c|}
\hline \multirow[b]{2}{*}{ Bechaviour } & \multicolumn{3}{|c|}{ Male } & \multicolumn{3}{|c|}{ Female } \\
\hline & $\begin{array}{c}\text { No. of } \\
\text { Subjects }\end{array}$ & $\begin{array}{l}\text { No. of } \\
\text { periodn }\end{array}$ & $W$ & $\begin{array}{c}\text { No. of } \\
\text { Subjects }\end{array}$ & $\begin{array}{l}\text { No. of } \\
\text { periodn }\end{array}$ & $W$ \\
\hline Contact with mother & 9 & 17 & $0.17^{* *}$ & 4 & 17 & 0.08 \\
\hline Within $2 \mathrm{~m}$ of mother & 9 & 17 & $0.15^{*}$ & 4 & 17 & $0.17^{*}$ \\
\hline Sucking+ & 11 & 7 & 0.21 & 6 & 5 & 0.24 \\
\hline Being groomed by mother & 9 & 17 & $0.21^{* *}$ & 4 & 17 & $0.23^{* *}$ \\
\hline Grooming mother $\S$ & 10 & 8 & $0.23^{*}$ & 4 & 17 & $0.28^{* *}$ \\
\hline $\begin{array}{l}\text { Grooming interactions with } \\
\text { mother/Contacot with mother } \dagger^{\dagger}\end{array}$ & 11 & 9 & $0.21^{*}$ & 4 & 17 & 0.08 \\
\hline $\begin{array}{l}\text { Beyond } 5 \mathrm{~m} \text { off mother/Off } \\
\text { mother }\end{array}$ & 9 & 17 & $0.09 \dagger$ & 4 & 17 & $0.13 \dagger$ \\
\hline
\end{tabular}

$\dagger P<0.1 ;{ }^{*} P<0.05 ;{ }^{* *} P<0.01$.

$\ddagger$ For males the data in the first seven periods and for females the data in the first five periodn were used because most of them ceased to suck during the second year.

$\S$ For males the data in eight periods covering their second and third years were used because they were rarely observed to groom their mothers in the other periods.

$\dagger \dagger$ For males the data up to the end of the second year were used because most males did not show the behaviour in all intervals for the remainder of the study.

を統計的に確認するために，ケンドールの一致 係数を求めた。Table 1 には，母子関係を表す 7 つの指標をもとに，オスの子ザルとメスの子ザ ルを別々にして，ケンドールの一致係数が示し てある。オスの子ザルでは，母ザルと身体接触 をしている時間, 母ザルの $2 \mathrm{~m}$ 以内にいる時 間，母ザルから毛づくろいしてもらう時間，母 ザルに毛づくろいする時間など， 7 指標のうち の 6 指標で有意な值が得られた。有意な值にな らなかった指標は, 母ザルの乳首を口に含む行 動だけであった。この行動は, 生存に直接結び つく行動であり，大きな個体差が持続すること はあり得ないだろう。メスの子ザルの間でも, オスの子ザルと類似した結果が得られた。すな わち，オスの子ザルもメスの子ザルも生後 4 年 間を通して，あるいは，かなり長い期間を通し て，母ザルとの関わり方は一定であったことを 意味している。言い換えるならば, 生後 4 年の 間に，母ザルと子ザルの関わり方は疎遠になっ ては行くが, この長い子ザル時代を通して, 子
ザルと比較的緊密な関わりを保持する母ザル， あるいは，子ザルとの関わりが比較的疎遠であ る母ザルは，どの時期でも概ね同じ個体なので ある。この事実は母子関係における恒常性が存 在することを意味している。

ニホンザルを対象にした研究から，子ザルの 成長にもかかわらず，それぞれの母ザルに特有 の子育てのスタイルは基本的には変わらないこ とが分かった。それでは, 母ザルは何回産んで も子育てのスタイルは変わらないのだろうか。 さらに，母の子育てのスタイルと成体になった 娘の子育てのスタイルは一緒なのだろうか?こ のような疑問に答える研究が真猿類のベルベッ トモンキー (Cercopithecus aethiops) とアカゲ ザル (Macaca mulatta) を対象にして行われて いる。

Fairbanks (1989) は屋外の放飼場のベルベッ トモンキー集団で生活している母ザルの中から 3 回から 10 回の子育てを経験した母ザル 11 頭 を選び出し，比較した。指標に用いたのは，母 
子の身体接触の頻度。Fig. 2 の横軸には 11 頭の 母ザルが優劣順位に従って左から並べてあり,

縦軸には生後 6 力月間の平均の母子の身体接触 の頻度が示してある。11 頭の中で最も高位の母 ザル Y は 5 回の子育てを行い, それぞれの子ザ ルとの平均の身体接触の頻度は， $40 \%$ 弱から $60 \%$ 弱の約 20\%の範囲におさまっている。他の 母ザルでも，その範囲は $10 \%$ か 20\%であっ た。しかし，それぞれの母ザルの中央値が示す ように, 11 頭の母ザルの間の個体差は顕著で あった。この結果は, 何回子育てしても子ザル との身体接触の頻度は大きく変わらなことを意 味する。すなわち，それぞれの母ザルが自分の 子育てのスタイルを持っており, そのスタイル は子育てのたびに踏襲されたのである。

これまでの研究では, 初産は経産よりも母子
の身体接触の頻度が高い, さらに, 優劣順位や 子ザルの性も大きく影響すると言われてきた。 しかし, Fig. 2 を見る限り, 出産歴, 順位, 子 ザルの性などの要因よりも，個体差そのものの 方が大きく, 且つ個体差が安定していることが 分かる。

Fairbanks (1989) は, さらに, 母ザルの子育 てのスタイルが娘の子育てのスタイルに影響す るのか否かも検討した。Fig. 3 の横軸は子ザル の時に母ザルと身体接触していた時間の割合 が，縦軸には母ザルとして自分が産んだ子ザル と身体接触をしていた時間の割合が示してあ る。子ザルの時と母ザルになってから子育てを しているときの両方の資料がある 15 頭のメス の值が，図には示してある。相関係数は $\mathrm{r}=$ $0.69(\mathrm{p}<0.01)$ 。子ザルとして経験した母子の

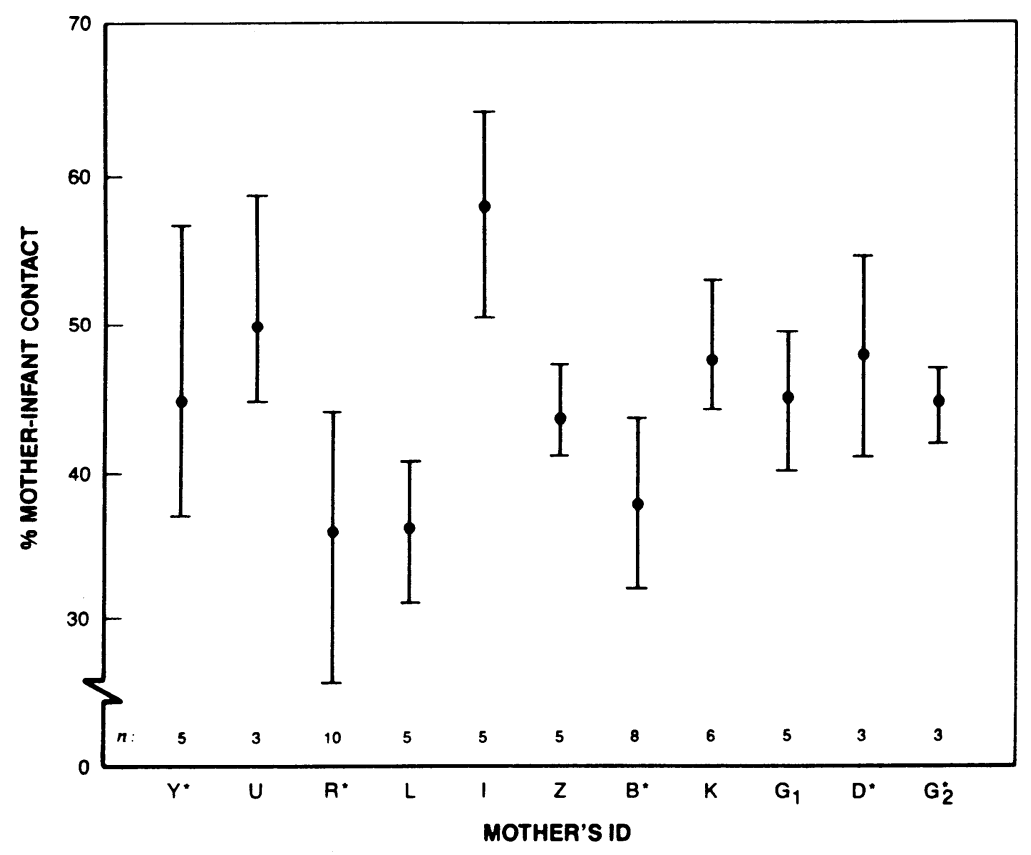

Fig. 2 Mean and range of mother-infant contact in vervet monkeys. Y, U. R, and L were high-ranking, I, $Z$, and $\mathrm{B}$ were middle-ranking, and $\mathrm{K}, \mathrm{G} 1, \mathrm{D}$, and $\mathrm{G} 2$ were low -ranking in their respective groups for most of the years represented here. Mothers marked with an* were feral -born. (Reproduced from Fairbanks, 1989, with permission of John Wiley \& Sons, Inc.) 


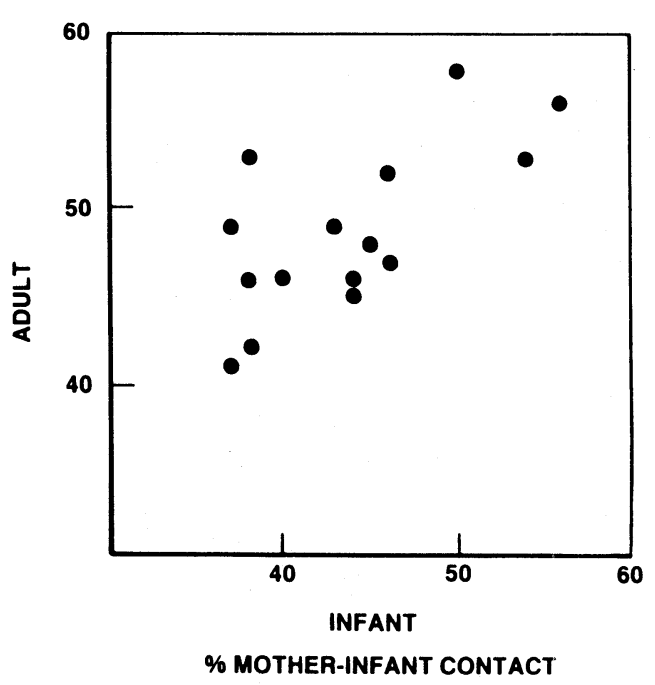

Fig. 3 Scatterplot of mother-infant contact experienced as an infant by mean mother-infant contact maintained as an adult. (Reproduced from Fairbanks, 1989, with permission of John Wiley \& Sons, Inc.)

身体接触の頻度と母ザルとして経験した身体接 触の頻度が有意に相関したのでる。つまり，こ の放飼場のベルベットモンキーの母ザルは, 育 てられたように育てたのである。

野生に近い状態の環境で生息するアカゲザル を研究した Berman (1990) も，母ザルから子ザ ルへの攻撃的行動を指標にして，母ザルは毎回 同じ様な子育てをすることを報告している。子 ザルの時に経験したように母ザルになったとき に子育てするとは必ずしも言えなかったが，成 体の娘の子育てスタイルは，母ザルが妹や弟を 子育てするのと同じスタイルであった。つまり， 母ザルが弟や妹を育てるように，娘は自分が産 んだ子ザルを育てたのである。

アカゲザルやベルベットモンキーの研究は, 母ザルはそれぞれの子育てスタイルをかなり頑 固に繰り返し，さらに，「育てられたように育て る」，あるいは「見たように育てる」傾向が存在 することを明らかにしたのである。

\section{3．子育ての柔軟性}

子育てにおける恒常性の存在は，母ザルが頑 固にそれぞれのスタイルを守るだけで，柔軟性 を欠いているということを意味しているのだろ うか。この質問に対する答えは，否である。通 常は，それぞれの母ザルが自分の子育てスタイ ルを守っていても, 状況が大きく変わるならば, それに即応して，子育てのスタイルも変えるこ とができるのである。淡路島ニホンザル集団で, 著者が記録したそのような柔軟な子育ての事例 を，以下に紹介する。

1960 年代から, 日本各地の慨付けされた二木 ンザル集団だけでなく，野生集団でも，指や肢 がなかったり，変形したりしている子ザルの出 生が報告されている。淡路島集団でも，1967 年 の䭒付け開始当初から，そのような先天性四肢 奇形個体は生まれていた。そして，1995 年の現 在に至るまで，ほぼ毎年そのような個体は生ま れている。

ニホンザルは生まれたときから，自分の力だ けで，母ザルの胸にしがみつくことができる。 だから，母ザルは歩くときも，木に登るときも， 胸にしがみついた子ザルを支える必要はない。 子ザルが母乳を飲むときも，母ザルが子ザルを 抱いている必要はない。他方, 指が欠損したり, 手首から先が完全に欠損した先天性四肢奇形の 子ザルでは，母ザルにしがみつくことが全くで きない。母ザルはそのようなハンディキャップ を持った子ザルを育てることができるのであろ うか。著者は，少なくとも50 頭以上の先天性四 肢奇形ザルの誕生を淡路島集団において記録し ているが，出産当初から子育てを放棄した母ザ ルを見たことがない。全ての母ザルが，片手で 子ザルを抱き抱え，他の 3 肢で移動するのであ る。Fig. 4 は，前肢は両方とも肘から先が欠損 し，後肢足首も変形している重度奇形のオスの 子ザルが母ザルと身体接触していた時間の割合 と，乳首を口に含んでいた時間の割合が，健常 の子ザルと比較して，示してある。どちらの行 


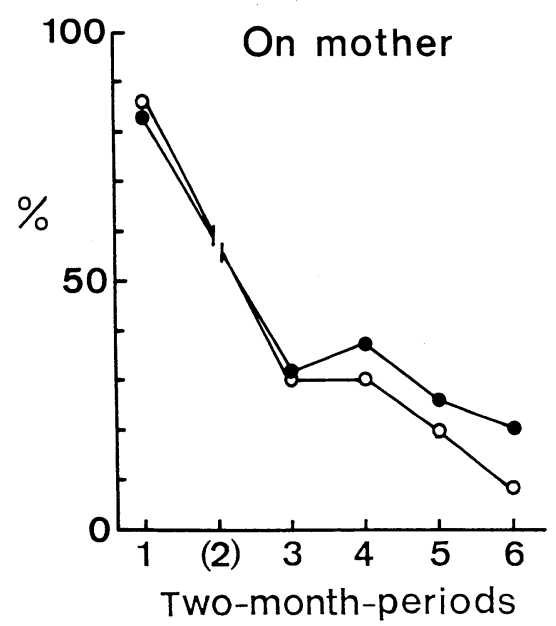

$\multimap$ Normal

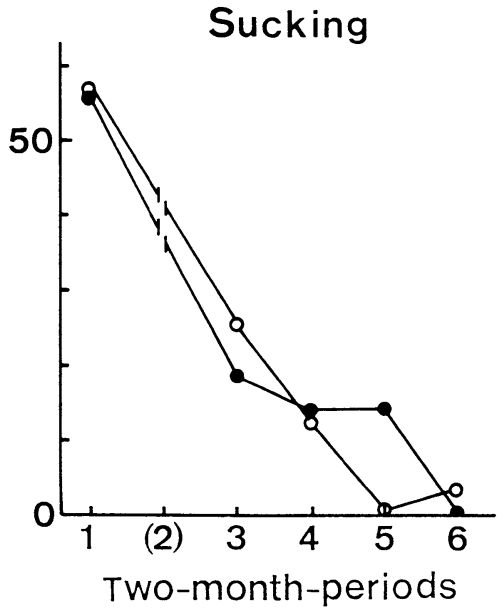

$\bullet$ Malformed

Fig. 4 Percentage of $10^{-}$sec intervals during which an infant was in contact with its mother (left) and an infant put a nipple in its mouth (right).

(Adapted from Nakamichi et al., 1983a)

動も, 生後 1 年間を通して, 重度奇形個体と健 常個体は近似した值を示している。この事実は, 重度奇形を負った子ザルのしがみつくことがで きないという障害を, その母ザルが十分に補完 していることを意味している (Nakamichi et al., 1983a）。また，両前肢ともに手首から先がな い重度奇形の子ザル, 前肢の指が変形している だけの軽度奇形の子ザル，そして，健常な子ザ ルの生後 3 ケ月間の行動発達を比較した場合に おいても, それぞれの母ザルは障害に適した行 動を示していた（Nakamichi, 1986)。

母ザルとの関係が緊密な関係から徐々に疎遠 な関係に移行する生後 2 年目以降では，どうで あろうか。後肢には障害がなかったが，前肢は 両方とも肘から先が欠損していたオスの子ザル は，生後 1 年目を終えるまでに後肢による安定 した二足歩行を獲得していた。しかし，このオ スの子ザルは, 生後 2 年目以降も, 母ザルの近 くで過ごすことが健常な同年歯のオスザルより も多く，母ザルからの毛づくろいも比較的頻繁 に受けていた。この関係は生後 4 年目を終える
頃まで続いた。健常なオスの子ザルとその母ザ ルの間ではありえない密接な関係が, 重度奇形 個体とその母ザルの間で長期にわたり持続して いたのである。つまり，重度の障害を負ったオ スの子ザルに対して，母ザルが特別の対応をし ていたのである (Nakamichi et al., 1983b)。

すでに述べたように，ニホンザルのオスでは， 生後 4,5 年目になると, 母ザルと一緒にいるこ とはきわめて稀になる。そのような年齢のオス の子ザルが，ワナ猟で，足首から先を失ってし まった。この大きなケガを負う直前までは，集 団の周辺部位置し，同年齢や年齢の近いオス の個体との関わりに多くの時間を費やしてい た。しかし，ケガと同時に，このオスの子ザル は母ザルの側で過ごすようになった。母ザルは 多くのメスや少数の成体オスからなる中心部に 位置していたが，オスの子ザルは母ザルに近接 して座り，母ザルが移動すればついて歩いた。 そして，間もなく母ザルから頻繁纪毛づくろい を受けるようにった。この年齢のオスにとって は例外的に緊密な母ザルとの関わりは，ケガが 


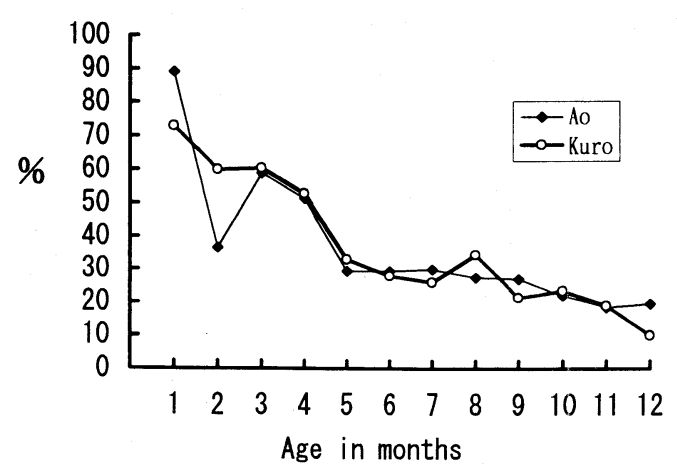

Fig. 5 Percentage of $10-$ sec intervals during which twins (Kuro and $A o$ ) were each in contact with their mother. (Adopted from Nakamichi, 1983)

㿇えるまでの約 2 カ月間続いた (中道, 1993 b)。 ニホンザルは，一産一仔が普通である。しか し，稀に双子を出産することもある。Fig. 5 は 双子のそれぞれが母ザルと身体接触をしている 時間の割合の生後 1 年間の変化を示したもので ある。母ザルが双子に対して，区別することな く対応しているのが分かる。一産一仔が一般的 なニホンザルが双子でも育てることができると 言うことは，ある程度の余裕をもって一仔を育 てているのかもしれない (Nakamichi, 1983)。

淡路島ニホンザル集団の母ザルは，先天性四 肢奇形を負った子ザルと双子の子ザルを育て， 大きなケガで後肢の足首を失った子ザルの，年 に不相応な密接な関わりを拒絶しなかった。こ れらの事実は，二ホンザルの子育てが置かれた 状況に適応的に変容するだけの極めて柔軟性に 富んだものであることを示唆している。模式的 に言うならば，種として有するある適応様式の 幅の中で，母ザルはそれぞれの子育てスタイル を維持する。これが通常の姿である。しかし， 上述のような特別な状況に置かれた場合には， それまでの子育てのスタイルを大きく変え，通 常では見られない積極性を発揮して子育てを行 うのである。もちろん，この積極性も種として 有する適応様式の枠組みの中の一部なのだが, 通常は顕在化しないのである。このようなこと
は，ここで示したニホンザルだけでなく，他の 多くのサル類でも妥当することである。

\section{4. 死亡した子ザルへの反応}

野外集団でニホンザルを観察しているものな らば誰でも，死んだ子ザルを抱いて歩く母ザル の姿を目にしているはずである。それほど，子 ザルが死亡してからも，子ザルに関わるニホン ザルの母ザルは珍しくない。もちろん，死んだ ときの子ザルの月齢, 母ザルの年齢や出産歴な どによって，どれくらいの期間死んだ子ザルを 抱き続けるのかは異なるようである（しかし， 残念ながら，このことに関する資料は報告され ていない)。死んだ子ザルを運ぶのはニホンザ ルだけでなく，旧世界ザル，新世界ザル，そし て類人猿の多くの種で見られる。つまり，死ん だ子ザルを抱き，運ぶことは，真猿類のサルに は特別なことではないのである。他方，真猿類 よりも下等な原猿類ではどうであろうか。

原猿類の野外での行動研究は, 真猿類に比べ て，大きく遅れている。野外での詳細な行動研 究, とりわけ母親行動についての報告はごくわ ずかである。原猿類の中で，死んだ子ザルに対 する母ザルの反応が観察されているのはマダガ スカルの南部乾燥地域に生息するワオキツネザ ル (Lemur catta) だけである（Nakamichi et al., 印刷中)。

ワオキツネザルの子ザルは, 真猿類の子ザル と同じように生まれたときから四肢の把握力を 持っており，母ザルの胸にしがみつくことがで きる。二ホンザルの母ザルは, 出産後 1 週間ほ どは, 時折, 胸にしがみつく子ザルを片手で下 から抱き上げるようにして歩くこともある。他 方，ワオキツネザルではそのような補助的な行 動を全く示さない。それでは，子ザルが死んだ ときどうするのか。

ワオキツネザルの母ザルは, 死亡して地面に 横たわる子ザルをなめたり, 触ったりしたが, 死んだ子ザルを抱きながら，集団の他のメン バーと一緒に移動することはなかった。子ザル 
の死亡から数時間は, 母ザルは集団と地面に横 たわる子ザルの間を何回か往復し, そして,

「ピャー」という音声を繰り返し発した。ワオ キツネザルは「ミャー」という音声を出して, 集団のメンバーの間のコミュニケーションに用 いる。「ピャー」は「ミャー」よりも澄んだ高音 域の音声であり, 生後 2,3 力月以内の子ザルを 見失った母ザルが稀に発するだけである。しか し，翌日になると，この音声は聞かれなくなる し，集団から離れて死んだ子ザルのもとへ戻る 行動も見られなかった。

ワオキツネザルは死んだ子ザルを運ばなかつ た。この事実は，ワオキツネザルが真猿類の母 ザルよりも母性が劣ると言うことを意味してい るのであろうか。否である。真猿類の母ザルは 死んだ子ザルを抱いて，集団と一緒に移動する ことができる。他方, ワオキツネザルは, 真猿 類ほど十分に四肢の把持能力が発達していない という制約のために，死んだ子ザルを運べない のである。しかし，「ピャー」という特有の音声 を繰り返し発すること, 集団と子ザルの間を往 復すること, この 2 つの事実から, ワオキツネ ザルの母ザルは死亡した子ザルに対しても母親 行動を示すことが明らかとなった。

死んだ子ザルを運ぶか, 否かという指標で霊 長類を見るならば，原猿類と真猿類の間に大き な溝が生じることになる。しかし，上述のよう に，ワオキツネザルの母ザルは，死んだ子ザル を運ぶ能力を持ってはいないが, 少なくとも死 後数時間にわたり，子ザルに対して関心を持続 させ, 時折, 母親行動を示した。従って, 死ん だ子ザルに対しても母親行動を示すか否かとい う指標で，霊長類の母性を見るならば，最も下 等な原猿類から, 新世界ザル, 旧世界ザル, 類 人猿まで，1つの連続したものとみなすことが できる。どこにも大きな溝は存在しないのであ る。死んだ子どもを約 1 力月も抱いて運ぶ野生 チンパンジー（Pan troglodytes）の母「ジレ」 を観察した松沢 (1995) は「ジレの姿は，子に対 する愛情, 死児への執着, 抱き続ける意志といつ た心の動きを感じさせた(p.125)」と書いてい る。ワオキツネザルでは, わずか 1 日だけ，特 有の音声を頻繁に発し, 死んだ子ザルと集団の 間を行き来するだけであった。しかし，そのわ ずかな期間に表出した行動から, チンパンジー の母ザルと共通する母性の萌芽をワオキツネザ ルの母ザルに認めることができるであろう。

\section{5.おわりに}

母子相互作用 (Mother-Infant Interactions) という言葉が示すように，母ザルと子ザルは互 いに影響し合うものであり，母ザルから子ザル への一方的な働きかけだけでも, その逆だけで もない。そのことを十分に知りながら,「子育て」 の言葉からも分かるように, 本稿では母ザルの 行動を中心に扱ってきた。そして,明らかになっ た事実は，状況によっては柔軟に変容するが, 通常はそれぞれの母ザルに特有の子育てス夕イ ルが保持されることであった。さらに，死んだ 子ザルに対する母ザルの行動の比較から, 下等 な原猿類から高等な真猿類まで，霊長類の母性 は 1 つの連続体として把握できたのである。

今後の課題は, 母ザルから子ザルだけでなく, 子ザルから母ザルへの働きかけをも含めて, 文 字どおり, 母子相互作用としての理解が必要で ある。そのためにも, 社会の中で生活する母ザ ルと子ザルがお互いにどのようにとらえている のかという認知に関する疑問に答えなければな らないだろう。また，母子関係の出発点を，子 ザルの誕生ではなく，妊娠中あるいは，それ以 前に設定した方がよいのかもしれない。

\section{REFERENCES}

Berman, C. N. 1990 Intergenerational transmission of maternal rejection rates among free -ranging rhesus monkeys. Animal Behaviour, 39, 329-337.

Fairbanks, L. A. 1989 Early experience and cross -generational continuity of mother-infant contact in vervet monkeys.

Developmental 
Psychobiology, 22, 669-681.

松沢哲郎 1995 『チンパンジーはちんぱんじん』 岩波書店（岩波ジュニア新書）

Nakamichi, M. 1983 Development of infant twin Japanese monkeys (Macaca fuscata) in a free -ranging group. Primates, 24, 576-583.

Nakamichi, M. 1986 Behavior of infant Japanese monkeys (Macaca fuscata) with congenital limb malformations during their first three months. Developmental Psychobiology, 19. 335-341.

Nakamichi, M. 1989 Sex differences in social development during the first four years in a free-ranging group of Japanese monkeys (Macaca fuscata). Animal Behaviour, 38, 737-748.

中道正之 1993 a 霊長類に抢ける母子関係の研 究の流れ 心理学評論 36, 151-170.
中道正之 1993 b ニホンザルにおける先天性四 肢奇形個体の行動 『ノンバーバル行動の実 験的研究』異常行動研究会編 朝倉書店 pp. 96-120.

Nakamichi, M., Fujii, H., \& Koyama, T. 1983a Behavioral development of a malformed infant in a free-ranging group of Japanese monkeys. Primates, 24, 52-66.

Nakamichi, M., Fujii, H., \& Koyama, T. 1983b Development of a congenitally malformed Japanese monkey in a free-ranging group during the first four years of life. American Journal of Primatology, 5, 205-210.

Nakamichi, M., Koyama, N., \& Jolly, A, (印刷中). Maternal Responses to dead and dying infants in wild troops of ring-tailed lemurs at the Berenty Reserve, Madagascar. International Journal of Primatology. 